University of South Florida

DIGITAL COMMONS

Digital Commons @ University of

@ UNIVERSITY OF SOUTH FLORIDA

South Florida

January 2014

\title{
Troglomorphic pseudoscorpions (Arachnida: Pseudoscorpiones) of northern Arizona, with the description of two new short-range endemic species
}

J. Judson Wynne, Ph.D.

Follow this and additional works at: https://digitalcommons.usf.edu/kip_articles

\section{Recommended Citation}

J. Judson Wynne, Ph.D., "Troglomorphic pseudoscorpions (Arachnida: Pseudoscorpiones) of northern Arizona, with the description of two new short-range endemic species" (2014). KIP Articles. 5471. https://digitalcommons.usf.edu/kip_articles/5471

This Article is brought to you for free and open access by the KIP Research Publications at Digital Commons @ University of South Florida. It has been accepted for inclusion in KIP Articles by an authorized administrator of Digital Commons @ University of South Florida. For more information, please contact digitalcommons@usf.edu. 


\title{
Troglomorphic pseudoscorpions (Arachnida: Pseudoscorpiones) of northern Arizona, with the description of two new short-range endemic species
}

\author{
Mark S. Harvey ${ }^{1,2,3,4,5}$ and J. Judson Wynne ${ }^{6}$ : ${ }^{1}$ Department of Terrestrial Zoology, Western Australian Museum, Locked \\ Bag 49, Welshpool DC, Western Australia 6986, Australia; ${ }^{2}$ Research Associate, Division of Invertebrate Zoology, \\ American Museum of Natural History, Central Park West at 79th Street, New York, New York 10024-5192, U.S.A; \\ ${ }^{3}$ Research Associate, California Academy of Sciences, 55 Music Concourse Drive, San Francisco, California 94118, \\ U.S.A; ${ }^{4}$ Adjunct, School of Animal Biology, University of Western Australia, Crawley, Western Australia 6009, \\ Australia; ${ }^{5}$ Adjunct, School of Natural Sciences, Edith Cowan University, Joondalup, Western Australia 6027, \\ Australia; 'Department of Biological Sciences, Colorado Plateau Biodiversity Center, Landscape Conservation \\ Initiative, Northern Arizona University, Box 5640, Flagstaff, Arizona 86011, U.S.A. E-mail: \\ mark.harvey@museum.wa.gov.au
}

\begin{abstract}
This study reports on the pseudoscorpion fauna of the subterranean ecosystems of northern Arizona, U.S.A. Our work resulted in the descriptions of two new species, Hesperochernes bradybaughi sp. nov. and Tuberochernes cohni sp. nov. (Chernetidae) and the range expansion of one species, Larca cavicola (Muchmore 1981) (Larcidae). All of these species were cave-adapted and found within caves on Grand Canyon-Parashant National Monument in northwestern Arizona. Based upon this work, the genus Archeolarca Hoff and Clawson is newly synonymized with Larca Chamberlin, and the following species are transferred from Archeolarca to Larca, forming the new combinations L. aalbui (Muchmore 1984), L. cavicola (Muchmore 1981), L. guadalupensis (Muchmore 1981) and L. welbourni (Muchmore 1981). Despite intensive sampling on the monument, the two new species were detected in only one cave. This cave supports the greatest diversity of troglomorphic arthropod species on the monument - all of which are short-range endemics occurring in only one cave. Maintaining the management recommendations provided by Peck and Wynne (2013) for this cave should aid in the longterm persistence of these new pseudoscorpion species, as well as the other troglomorphic arthropods.
\end{abstract}

Keywords: Nearctic, troglomorphy, troglobite, new synonymy, cave

urn:Isid:zoobank.org:pub:A15CB9DB-5B36-4A7C-8052-08E2EC1F4D34

The pseudoscorpion fauna of North American caves is moderately well known, thanks largely to the efforts of J.C. Chamberlin, C.C. Hoff, E.M. Benedict, D.R. Malcolm and W.B. Muchmore who have characterized and described many different North American troglobites and troglophiles. There are currently 144 named species found in cave habitats across the United States including six species in five families from Arizona: Pseudogarypus hypogeus Muchmore 1981 (Pseudogarypidae), Albiorix anophthalmus Muchmore 1999 (Ideoroncidae), Chitrellina chiricahuae Muchmore, 1996 (Syarinidae), Archeolarca cavicola Muchmore 1981, A. welbourni Muchmore 1981 (Larcidae) and Tuberochernes ubicki Muchmore 1997 (Chernetidae) (Muchmore 1996; Muchmore \& Pape 1999; Harvey \& Muchmore 2013). Only A. anophthalmus and C. chiricahuae had troglobitic modifications including the complete lack of eyes and pallid body color (Muchmore 1996; Muchmore \& Pape 1999; Harvey \& Muchmore 2013), whereas the others are less obviously modified with only the slightly attenuated appendages hinting at an obligate subterranean existence (Muchmore 1981, 1997).

Prior to this work, all of these cavernicolous species from Arizona occurred south of the Colorado River with $P$. hypogeus, A. cavicola and A. welbourni from northern Arizona (Coconino County) and $A$. anophthalmus, C. chiricahuae and T. ubicki from south-eastern Arizona (Pima, Cochise and Santa Cruz Counties, respectively). During biological inventories of caves on the Grand Canyon-Parashant National Monument (hereafter referred to as Parashant) in northwestern Arizona, one of us (J.J.W.) and colleagues found representatives of three different pseudoscorpion species, which are the subject of this study.

Over the past several years, Parashant caves have yielded other significant and interesting arthropod species-many of which are restricted to the cave environment. These include two new genera (comprising two new species) - a book louse (order Psocoptera, family Sphaeropsocidae: Troglosphaeropsocus voylesi Mockford 2009 (Mockford 2009), and a cave cricket (family Rhaphidophoridae: cf. Ceuthophilus n. gen. n. sp., Cohn and Swanson, unpublished data). This work also resulted in the identification of several cave-adapted and cavelimited species including a leiodid beetle, Ptomaphagus parashant Peck and Wynne 2013 (Peck \& Wynne 2013), an undescribed species of centipede (family Anopsobiidae; Wynne, unpublished data), an undescribed Isopod species, Brackenridgia n. sp. (S. Taiti, in litt.), and a recently described cave limited millipede, Pratherodesmus voylesi Shear 2009 (Shear et al. 2009). Additionally, three new species of trogloxenic beetles were reported from Parashant caves including Eleodes wynnei Aalbu, Smith, and Triplehorn 2012 (Tenebrionidae; Aalbu et al. 2012), an undescribed species of the carabid beetle genus Rhadine LeConte (Carabidae: the perlevis species-group; T.C. Barr, in litt.), and an undescribed carabid beetle species Pterostichus Stephens (Carabidae, K. Will, in litt.).

\section{METHODS}

The junior author and colleagues sampled caves on Grand Canyon-Parashant National Monument during 4-14 August 
2005, 1-6 May 2007, 16-25 August 2007, 12-21 May 2008, and 5-12 March 2009. They sampled all caves identified as having deep zone like conditions $(n=10)$. Given the short duration of study (between two to four site visits), and potential seasonal effects, confidently identifying this zonal environment was not possible. The cave deep zone is required habitat for cave-adapted arthropods and is characterized by complete darkness, stable temperature, a near-water saturated atmosphere and limited to no airflow (as in Howarth 1980, 1982). Parashant is located in northwestern Arizona, encompasses approximately $4,451 \mathrm{~km}^{2}$, and is characterized by rugged terrain containing deeply incised canyons, mesas, and mountains. Vegetation zones include Mojave Desert containing creosote bush (Larrea tridentata) and Joshua trees (Yucca brevifolia) at lower elevations, gradating through Great Basin pinyon (Pinus edulis) and juniper (Juniperus spp.) woodlands to Colorado Plateau grasslands and Ponderosa pine (Pinus ponderosa) forest with aspen (Populus tremuloides) groves on Mt. Trumbull (elevation 2,447 m). All of the caves referred to in this paper were located within the Supai, Kaibab, or Redwall limestone formations. Elevation for the caves that were studied ranges from 736 to $1,590 \mathrm{~m}$.

Although we inventoried 10 Parashant caves, we provide descriptions for only the three caves (PARA-1001, PARA2204 and PARA-3503) where pseudoscorpions were detected. PARA-1001 Cave was the second most biologically diverse cave on Parashant (Wynne, unpublished data), and supports the largest known cricket roost in northern Arizona (Wynne \& Voyles 2014). A small solution cave within the Kaibab limestone, it had a total surveyed length and depth of $76.2 \mathrm{~m}$ and $10.4 \mathrm{~m}$, respectively. This cave had a small south-facing vertical entrance $\left(135^{\circ}\right.$ aspect) at bottom center of a large sinkhole. Vegetation was characterized as juniper scrublands at $1,585 \mathrm{~m}$ elevation, and was located on the north side of the lower Colorado River along the western extent of the Grand Canyon. PARA-2204 Cave was the most biologically diverse cave on the monument (Wynne, unpublished data). The deepest extent of this cave contained active speleothem formations and supported a near-saturated water atmosphere year-round. Located within the Supai formation, this large solution cave (total surveyed length $175 \mathrm{~m}$ ) was comprised of several sinuous phreatic passages. This cave has one horizontal entrance $\left(330^{\circ}\right.$ aspect) and was situated within a canyon near the base of the canyon's north-face. Located at 1,272 m elevation, this cave occurred within the vegetation transition zone of Mojave Desert scrub and juniper woodlands. PARA3503 Cave was a dry cave with no evidence of recent speleothem activity, and supported a summer roost of bats, Myotis sp. (Wynne, unpublished data). The cave had a large horizontal entrance $\left(135^{\circ}\right.$ aspect) situated upon a high bench (1,102 $\mathrm{m}$ elevation on an exposed cliff face). This cave was situated along the south-face of one of the largest canyons draining into the Colorado River from the north. Occurring within the Redwall formation, this large solution cave contained $540 \mathrm{~m}$ of surveyed length with an estimated survey depth of $14.2 \mathrm{~m}$. Vegetation was characterized as Mojave Desert scrub.

The work conducted in 2005 was part of a biological baseline study [refer to Wynne \& Voyles (2014) for a description of sampling methods]. Later (between 2007 and
2009), these caves were systematically sampled to characterize the cave-dwelling arthropod communities. Interval sampling using baited pitfall traps, timed searches, and opportunistic sampling techniques were used. To apply these techniques, detailed maps for each cave were required. For interval sampling, we established up to 10 sampling intervals (which included a sampling station at either wall and one at cave centerline for a total of $\leq 3$ sampling stations per interval). We used $10 \%$ of the total cave length to establish the sampling interval (e.g., for a 1,000 $\mathrm{m}$ long cave, the sampling interval was every $100 \mathrm{~m})$.

At each sampling station, we deployed live capture baited pitfall traps and conducted timed searches. For pitfall traps, we used two $907 \mathrm{~g}$ stacked plastic containers $(13.5 \mathrm{~cm}$ high, $10.8 \mathrm{~cm}$ diameter rim and $8.9 \mathrm{~cm}$ base). A teaspoon of peanut butter was used as bait and placed in the bottom of the exterior container. At the bottom of the interior container, we made several dozen holes so the bait could "breathe" to attract arthropods (e.g., Barber 1931). Attempts were made to counter-sink each pitfall trap within the cave sediment or rockfall. When this was not possible, we built ramps around each trap using local materials (e.g., rocks, wooden debris, etc.) so arthropods could access the trap and fall in (e.g., Ashmole et al. 1992). To discourage small mammals, we placed small rocks around the edges of the trap and then covered the mouth of the trap with a cap rock. Pitfall traps were deployed for three to four days (a three day deployment occurred once due to scheduling constraints). For timed searches, we established a $1 \mathrm{~m}$ radius around each sampling station (where the pitfall trap would be deployed) and searched for arthropods within that $\sim 3 \mathrm{~m}$ circle. A one to three minute timed search (one minute if no arthropods were observed, three minutes if arthropods were detected) was conducted before pitfall trap deployment and prior to trap removal.

Opportunistic collecting was executed by two to three trained observers as they traversed the length of each cave. This technique was applied as the observers were in transit between sampling intervals while deploying and removing pitfall traps and conducting timed searches. Opportunistic collecting was not conducted while at sampling stations and was resumed only when the observers were in transit once again. This technique was used at least twice per cave (both during pitfall trap deployment and retrieval trips). For example, a cave containing 10 sample station arrays, there were 27 individual "random walks" per site visit (i.e., nine random walk samples times three observers collecting along their between stations). Because we conducted two site visits per cave, there would be a total of 54 samples. For one cave, PARA 1001 Cave, we had two observers conduct the opportunistic collecting.

An alpha-numeric coding system developed by the National Park Service (NPS) was used to safeguard the location of both caves and their resources. We only provide generalized latitude and longitude coordinates of the area to keep the precise location of the cave confidential. Parashant National Monument headquarters in Saint George, Utah has the cipher table with cave codes. A copy of this paper with actual cave names is on file at both monument headquarters, National Park Service and the National Cave and Karst Research Institute, Carlsbad, New Mexico. 
Specimens representing three species collected by one of us (J.J.W.) and colleagues form the basis of this study. All specimens were collected and stored in $70 \%$ ethanol. The holotypes of both new species and specimens of the known species are deposited in the Museum of Northern Arizona, Flagstaff, Arizona (MNA). Temporary slide mounts were prepared by mounting them on microscope slides with 10 or $12 \mathrm{~mm}$ coverslips supported by small sections of $0.25,0.35$ or $0.50 \mathrm{~mm}$ diameter nylon fishing line in a drop of lactic acid at room temperature for two or more days. After study the specimens were rinsed in water and returned to $75 \%$ ethanol with the dissected portions placed in $12 \times 3 \mathrm{~mm}$ glass genitalia microvials (BioQuip Products, Inc.). All specimens were studied using a Leica DM2500 compound microscope and illustrated with the aid of a drawing tube. Measurements were taken at the highest possible magnification using an ocular graticule. Terminology and mensuration mostly follow Chamberlin (1931), with the exception of the nomenclature of the pedipalps, legs and with some minor modifications to the terminology of the trichobothria (Harvey 1992), cheliceral setation (Harvey \& Edward 2007), cheliceral rallum (Judson 2007) and faces of the appendages (Harvey et al. 2012).

\section{TAXONOMY}

Family Larcidae Harvey 1992

Larca Chamberlin 1930

Larca Chamberlin 1930:616.

Archeolarca Hoff and Clawson 1952:2-3. Syn. nov.

Type species._Larca: Garypus latus Hansen 1884, by original designation.

Archeolarca: Archeolarca rotunda Hoff and Clawson 1952, by original designation.

Remarks. - The genus Larca was created by Chamberlin (1930) for the type species L. lata (Hansen) from Europe and L. granulata (Banks 1891) from eastern U.S.A. Since then, other species have been added from Europe (Beier 1939a; Gardini 1983; Henderickx \& Vets 2002; Zaragoza 2005) and North America (Hoff 1961; Benedict \& Malcolm 1978; Muchmore 1981). Archeolarca was described for the type species $A$. rotunda which was collected from pack rat middens and porcupine nests in Utah (Hoff \& Clawson 1952). Since then, four additional species have been described from other parts of western North America, all from cave ecosystems (Muchmore 1981, 1984), and $A$. rotunda has been found in New Mexico and Oregon (Hoff 1956a; Benedict \& Malcolm 1978). Archeolarca only differs from Larca in the possession of four trichobothria on the movable chelal finger of adults, whereas species of Larca have only two or three trichobothria (e.g. Hoff 1961; Benedict \& Malcolm 1978; Muchmore 1981; Gardini 1983; Muchmore 1984, 1990; Henderickx \& Vets 2002; Zaragoza 2005). Most adult specimens from the Parashant have four trichobothria on the movable chelal finger (Fig. 12), consistent with being a species of Archeolarca, but one male has four on the right chela and three on the left (Fig. 11) raising the issue of whether the genera should be retained.

The maintenance of garypoid genera based solely on trichobothrial number has been abandoned for several other groups including the garypid genera Anagarypus Chamberlin
1930 with seven trichobothria on the fixed finger and one or two on the movable finger forming a pattern of 7/1-2 (Muchmore 1982), Eremogarypus Beier 1955, with a pattern of 5-8/1-3 (e.g., Beier 1962; Beier 1973), Synsphyronus Chamberlin 1930, with a pattern of 5-8/1-3 (e.g., Chamberlin 1943; Harvey 1987b, 2011) and Thaumastogarypus Beier 1947, with a pattern of 7-8/3-4 (e.g. Beier 1947; Mahnert 1982), and the geogarypid genus Geogarypus Chamberlin 1930 in which adults normally have an 8/4 pattern, but G. bucculentus Beier 1955 and G. connatus Harvey 1987 have a 7/4 pattern (Harvey 1986, 1987a). Intra-specific variation in the number of trichobothria of the movable chelal finger has been reported in the genus Serianus Chamberlin 1930 (Garypinidae). Hoff (1950) found that a small series of specimens of $S$. minutus Hoff 1950 (now known as S. argentinae Muchmore 1981 due to secondary homonymy of the original name) included adults with the normal four trichobothria on the movable chelal finger, as well as some with only two or three trichobothria. Similarly, Mahnert (1988) found that the type series of Paraserianus bolivianus Beier 1939 possessed three or four trichobothria on the movable chelal finger. Given that the main feature used to substantiate the genus Paraserianus by Beier (1939b) was the presence of only three such trichobothria (as opposed to four in Serianus), Mahnert (1988) placed Paraserianus as a synonym of Serianus.

Comparison of specimens of many species of Larca and Archeolarca by one of us (M.S.H.), including the type species of both genera, has revealed no other significant differences that could be considered to maintain distinct genera, and Archeolarca is here regarded as a synonym of Larca, resulting in the following new combinations: L. aalbui (Muchmore 1984), comb. nov., L. cavicola (Muchmore 1981), comb. nov., $L$. guadalupensis (Muchmore 1981) comb. nov. and L. welbourni (Muchmore 1981) comb. nov.

\section{Larca cavicola (Muchmore) comb. nov.}

(Figs. 1-14)

Archeolarca cavicola Muchmore 1981: 55-56, Figs. 11, 12.

Material examined.-U.S.A.: Arizona: Mohave County: 1 male, PARA-3503 Cave, Grand Canyon-Parashant National Monument, ca. UTM 0247400 N, 4020000 E, Zone 12S, baited pitfall trap 1A, 20 May 2008, J.J. Wynne (MNA); 1 female, same data except baited pitfall trap 1C, 6 March 2009, J.J Wynne (MNA); 1 tritonymph, 1 deutonymph, same data except trap 2B, 10 March 2009, J.J. Wynne (MNA); 1 tritonymph, same data except trap 7A (MNA); 1 tritonymph, same data except opportunistic collecting in a possible deep zone (MNA); 1 male, PARA-2204 Cave, Grand Canyon-Parashant National Monument, ca. UTM $025100 \mathrm{~N}, 4041000 \mathrm{E}$, Zone 12S, M, baited pitfall trap 2B, 17 May 2008, J.J. Wynne (MNA); 1 female, same data except 20 May 2008 (MNA); 1 tritonymph, same data except trap 1A (MNA); 1 male, same data except trap 1B (MNA).

Diagnosis._Larca cavicola resembles the other species previously included in the genus Archeolarca in possessing four trichobothria on the movable chelal finger, but occasionally this is reduced to three trichobothria. It differs from these species by having reduced eyes, especially the posterior pair, which are noticeably smaller than the anterior pair. 


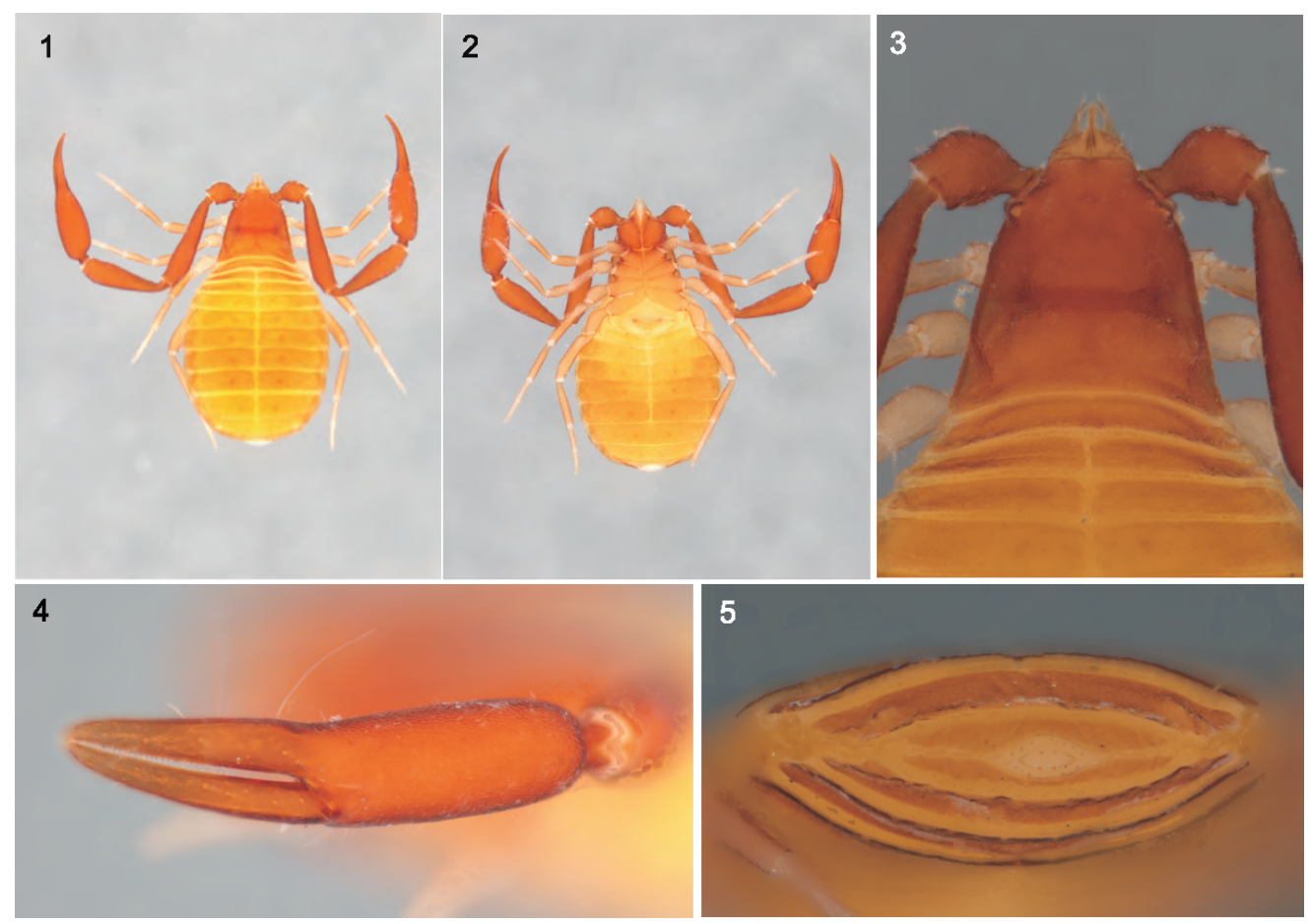

Figures 1-5.-Larca cavicola (Muchmore), male from PARA-2004 Cave: 1. Body, dorsal; 2. Body, ventral; 3. Carapace, dorsal; 4. Left chela, lateral; 5. Anal region, posterior.

Description.-Adults: Color: carapace, pedipalps and coxae deep red-brown, abdomen pale red-brown and legs pale yellow-brown.

Chelicera: with 4 setae on hand, with $s b s$ absent, and 1 subdistal seta on movable finger (Fig. 7); all setae acuminate; seta $b s$ slightly shorter than others; with 2 dorsal lyrifissures and 1 ventral lyrifissure; galea of $s$ and $q$ very long with 3 terminal rami, rami of male smaller than on female; rallum of 4 blades, the most distal blade with several serrations on leading edge, other blades smooth; serrula exterior with 14 ( $\left.{ }^{\text {t}}\right)$, 16 ( $)$ blades; lamina exterior present.

Pedipalp (Fig. 9): most surfaces of trochanter, femur, patella and chelal hand lightly and sparsely granulate, chelal fingers smooth; trochanter, femur, patella and chelal hand with prominent, curved, slightly denticulate setae arranged sparsely; patella with 3 small sub-basal lyrifissures; trochanter

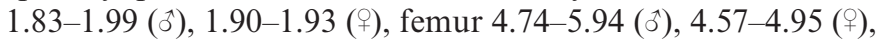
patella 3.63-4.47 (3), 3.69-3.94 (\%), chela (with pedicel) 4.47$5.28\left({ }^{3}\right), 4.08-4.54$ ( $)$, chela (without pedicel) 4.22-5.02 (के), 3.85-4.26 ( $)$, hand (with pedicel) 2.17-2.49 (3), 1.94-2.08 (\%) $\times$ longer than broad, movable finger (with pedicel) $0.96-1.01$ (o), $0.99-1.00$ ( + ) $\times$ longer than hand. Fixed chelal finger with 8 trichobothria, movable chelal finger with 4 trichobothria (Fig. 12), although $s b$ absent from left chela of one male (Fig. 11): $e b, e s b, i b$ and ist situated subbasally, est, isb and it submedially, et subdistally, and est opposite $i t ; b$ and $s b$ situated subbasally, and $s t$ and $t$ situated submedially, with $s t$ situated very close to $t$; patch of microsetae not present on external margin of fixed chelal finger near et. Venom apparatus present in both chelal fingers, venom ducts fairly short, terminating in nodus ramosus slightly distal to et in fixed finger (Figs. 11, 12). Chelal teeth pointed, slightly retrorse, becoming rounded basally; fixed finger with $32(\hat{o}$, क) teeth; movable finger with $32(\hat{0}), 33$ ( + ) teeth; accessory teeth absent.

Carapace (Figs. 3, 6): 0.77-0.86 (今), $0.74(+) \times$ longer than broad; anterior margin straight; with 2 pairs of rounded corneate eyes, tapetum present; with 31 ( $\left.{ }^{3}\right), 32$ (\%) setae, arranged with $4(\hat{\delta},+)$ near anterior margin and $4(\hat{\sigma}, \rho)$ near posterior margin; with 1 deep, broad median furrow.

Coxal region: manducatory process rounded with 1 small sub-oral seta, and 9 (今), 12 (\%) additional setae; median maxillary lyrifissure large, rounded and situated submedially; posterior maxillary lyrifissure rounded. Coxae I to IV becoming progressively wider. Chaetotaxy of coxae I-IV: \$, 6: 6: 6: 14; ; , 6: 7: 9: 16 .

Legs: femora I and II longer than patellae; junction between femora and patellae III and IV very angulate; femora III and IV much smaller than patellae III and IV; femur + patella of leg IV $5.92\left({ }^{1}\right), 5.27(+) \times$ longer than broad (Fig. 10); metatarsi and tarsi not fused; tarsus IV without tactile seta; subterminal tarsal setae arcuate and acuminate; claws simple; arolium much longer than claws, not divided.

Abdomen: tergites II-X and sternites IV-VIII of male and female with medial suture line fully dividing each sclerite, sternite IX partially divided. Tergal chaetotaxy: $\widehat{\sigma}, 4: 6: 10: 10$ : 11: 12: 11: 10: 10: 6 (arranged T4T): 7: 2; क , 6: 5: 7: 9: 10: 11: 11: 13: 9: 6 (arranged T4T): 8: 2; tergites I-X uniseriate. Sternal chaetotaxy: o, 19: (0) $19[3+3](0):(0) 6(0): 7: 9: 7: 8:$ 8: 6: 3: 2 ; + , 14: (0) 8 (0): (0) 4 (0): 6: 7: 6: 8: 9: 6: 4: 2; sternites IV-X uniseriate; $\delta$ and + sternite II and III with all setae situated near posterior margin. Spiracles with helix. Anal plates (tergite XII and sternite XII) situated between tergite XI and sternite XI, and surrounded by desclerotized region of 

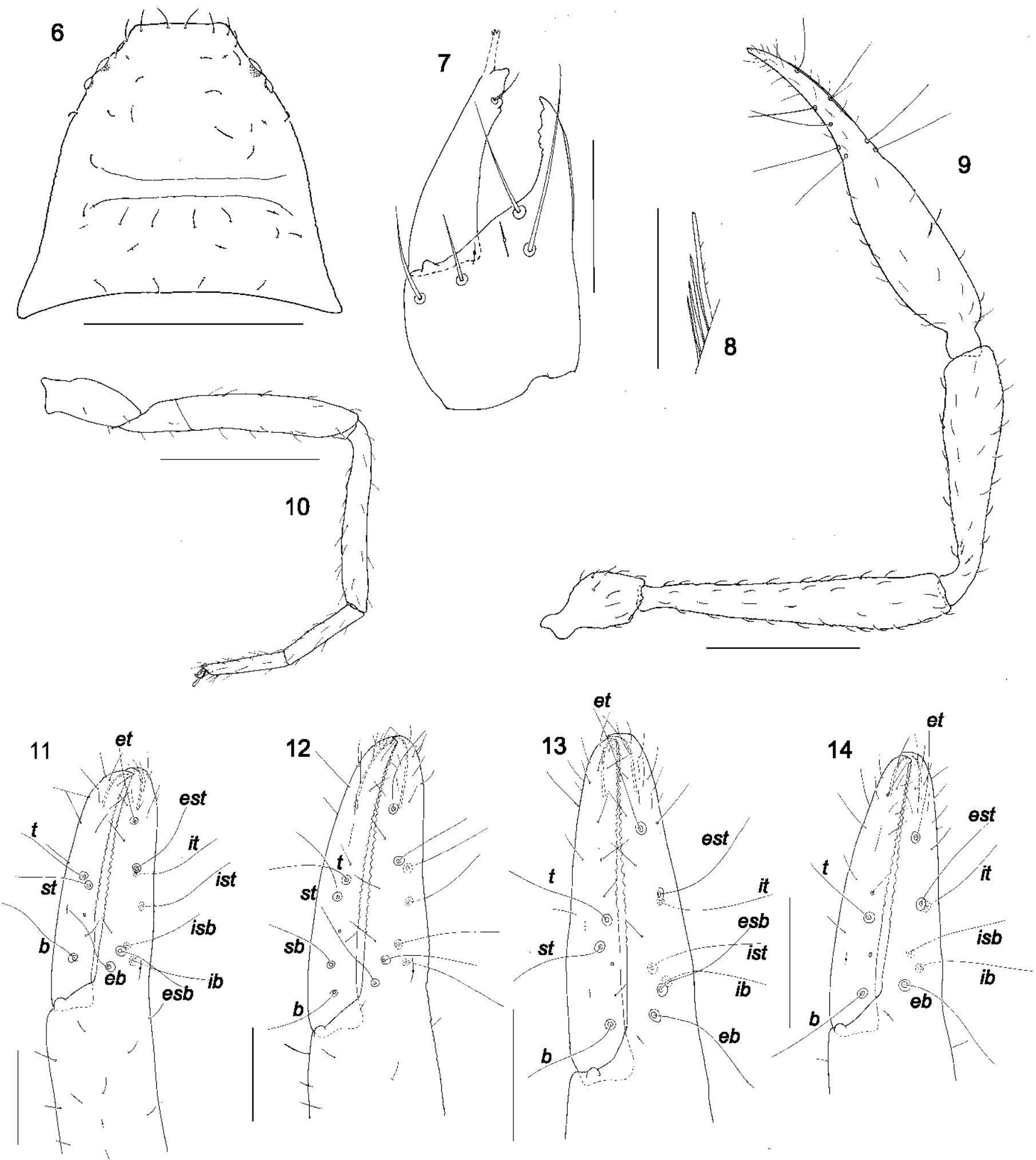

Figures 6-14.-Larca cavicola (Muchmore), specimens from PARA-3503 Cave: 6. Carapace, dorsal, male; 7. Chelicera, dorsal, male; 8. Rallum, lateral, male; 9. Right pedipalp, dorsal, male; 10. Left leg IV, male; 11. Left chela, lateral, male; 12. Left chela, lateral, female; 13. Left chela, tritonymph; 14. Left chela, deutonymph. Scale lines =0.1 mm (Figs. 7, 8), $0.2 \mathrm{~mm}$ (Figs. 11-14), 0.5 mm (Figs. 6, 9, 10). 
tergite XI and sternite XI; sternite XI with ca. 18 (ơ), 24 (†) small lyrifissures. Pleural membrane finely wrinkled-plicate; without any setae.

Genitalia: male: very similar to that described for L. laceyi Muchmore, 1981 by Muchmore (1981). Female with 1 pair of lateral cribriform plates and 2 pairs of median cribriform plates; spermathecae absent.

Dimensions: male (PARA-3503 Cave) followed by other males (where applicable): Body length 2.40 (2.14-2.42). Pedipalps: trochanter 0.371/0.186 (0.351-0.387/0.192-0.207), femur $1.021 / 0.172(0.923-0.976 / 0.187-0.206)$, patella $0.859 /$ $0.192(0.768-0.832 / 0.200-0.229)$, chela (with pedicel) $1.220 /$ 0.231 (1.173-1.286/0.262-0.272), chela (without pedicel) 1.160 (1.106-1.216), hand length 0.576 (0.569-0.622), movable finger length $0.582(0.547-0.595)$. Chelicera $0.200 / 0.115$, movable finger length 0.130 . Carapace $0.605 / 0.784$ (0.621-0.656/0.7630.772 ); anterior eye diameter 0.059 , posterior eye diameter 0.043. Leg I: femur 0.382/0.090, patella 0.249/0.092, tibia $0.350 /$ 0.067 , metatarsus $0.252 / 0.042$, tarsus $0.218 / 0.042$. Leg IV: femur + patella $0.740 / 0.125$, tibia $0.605 / 0.079$, metatarsus $0.285 / 0.055$, tarsus $0.270 / 0.048$.

Female (PARA-3503 Cave) followed by other female (where applicable): Body length 2.85 (2.72). Pedipalps: trochanter $0.422 / 0.219(0.408 / 0.215)$, femur $1.108 / 0.224(0.978 / 0.214)$, patella $0.992 / 0.252(0.822 / 0.223)$, chela (with pedicel) $1.394 /$ 0.307 (1.304/0.320), chela (without pedicel) 1.309 (1.232), hand length 0.640 (0.621), movable finger length 0.643 (0.616). Chelicera 0.240/0.131, movable finger length 0.150. Carapace $0.708 / 0.960)$; anterior eye diameter 0.049 , posterior eye diameter 0.048 . Leg I: femur $0.410 / 0.103$, patella $0.289 / 0.117$, tibia $0.382 / 0.075$, metatarsus $0.261 / 0.059$, tarsus $0.237 / 0.048$. Leg IV: femur + patella $0.828 / 0.157$, tibia $0.660 / 0.095$, metatarsus $0.300 / 0.067$, tarsus $0.282 / 0.058$.

Tritonymph: Color: carapace, pedipalps and coxae redbrown, abdomen pale red-brown and legs pale yellow-brown.

Chelicera: with 4 setae on hand and 1 on movable finger; galea long and slender with 3 terminal rami.

Pedipalp: trochanter 1.97, femur 5.05, patella 3.90, chela (with pedicel) 4.58 , chela (without pedicel) 4.32 , hand (without pedicel) $2.17 \times$ longer than broad, and movable finger $1.02 \times$ longer than hand (without pedicel). Fixed chelal finger with 7 trichobothria, movable chelal finger with 3 trichobothria (Fig. 13): eb, esb, ist and ib situated basally; est and it medially; et distally, isb absent; $b$ subbasally, st and $t$ submedially, $s b$ absent. Fixed chelal finger with 26 teeth; movable finger with 22 teeth.

Carapace: $0.85 \times$ longer than broad; with 2 pairs of small rounded corneate eyes; with 4 setae near anterior margin and 3 near posterior margin; with deep median furrow.

Legs: much as in adults.

Abdomen: tergal chaetotaxy: 4: 4: 6: 7: 8: 7: 8: 6: 6: 6 (arranged T4T): 7: 2. Sternal chaetotaxy: 2: (0) 7 (0): (0) 3 (0): 4: 4: 4: 5: 6: 4: 2: 2 .

Dimensions (mm) (PARA-3503 Cave): Body length 1.75. Pedipalps: trochanter $0.314 / 0.159$, femur $0.768 / 0.152$, patella $0.643 / 0.165$, chela (with pedicel) $1.040 / 0.227$, chela (without pedicel) 0.981 , hand length 0.493 , movable finger length 0.501 . Carapace 0.544/0.640.

Deutonymph: Color: carapace, pedipalps and coxae pale red-brown, abdomen and legs pale yellow-brown.
Chelicera: with 4 setae on hand and 1 on movable finger; galea long and slender with 3 terminal rami.

Pedipalp: trochanter 2.11, femur 5.16, patella 3.50 , chela (with pedicel) 4.19, chela (without pedicel) 3.94, hand (without pedicel) $2.02 \times$ longer than broad, and movable finger $0.97 \times$ longer than hand (without pedicel). Fixed chelal finger with 6 trichobothria, movable chelal finger with 2 trichobothria (Fig. 14): eb, ist and ib situated basally; est and it medially; et distally; it subdistally, esb and isb absent; $b$ subbasally, $t$ submedially, $s b$ and $s t$ absent. Fixed chelal finger with 24 teeth; movable finger with 21 teeth.

Carapace: $0.82 \times$ longer than broad; with 2 pairs of small rounded corneate eyes; with 4 setae near anterior margin and 4 near posterior margin; with deep median furrow.

Legs: much as in adults.

Abdomen: tergal chaetotaxy: 4: 4: 4: 6: 6: 6: 6: 6: 6: 6 (arranged T4T): 4: 2. Sternal chaetotaxy: 0: (0) 2 (0): (0) 2 (0): 3: $2: 4: 4: 4: 4: 4: 2$.

Dimensions (mm) (PARA-3503 Cave): Body length 1.49. Pedipalps: trochanter $0.278 / 0.132$, femur $0.629 / 0.122$, patella $0.514 / 0.147$, chela (with pedicel) $0.850 / 0.203$, chela (without pedicel) 0.800 , hand length 0.410 , movable finger length 0.397 . Carapace 0.490/0.600.

Remarks. - Larca cavicola was described from a single female collected in Cave of the Domes, Grand Canyon National Park, Coconino County, Arizona (Muchmore 1981). The new specimens were taken from two different caves within the Parashant, PARA-3503 Cave and PARA2204 Cave, expanding the known range of this species some $160 \mathrm{~km}$ west of the type locality. Specimens from both cave localities have shorter and slightly thinner pedipalpal segments than the female holotype. In addition, the PARA-3503 Cave specimens have slightly longer and thinner pedipalps than those from PARA-2204 Cave. There do not appear to be any other morphological features that would warrant the recognition of more than one species amongst these specimens which are all here attributed to L. cavicola. As noted by Muchmore (1981), this species shows some obvious troglomorphic features consistent with an obligate subterranean existence including long, slender pedipalps and legs, reduced posterior eyes, and fewer setae on the carapace. Given the findings of both Muchmore (1981) and the present study, we consider this species to be troglobitic. A useful measure of troglomorphic adaptation in larcid pseudoscorpions was proposed by Gardini (1983), who found that the ratio pedipalpal femur length/carapace length was lower in epigean species of Larca than in cavernicolous species. This pattern was also observed in two new Spanish species of Larca (Zaragoza 2005). A similar condition is found in the species formerly described in Archeolarca. The epigean L. rotunda has a low ratio of 1.20 (male), 1.36 (female) (Hoff \& Clawson 1952), whereas the cavernicolous species generally have higher ratios: L. aalbui 1.57 (male), L. cavicola 1.44 (female), $L$. guadalupensis 1.34 (female) and L. welbourni 1.47 (female) (Muchmore 1981, 1984). The ratios of the new specimens of $L$. cavicola recorded here [1.69 (male), 1.56 (female)] are higher than the female holotype, but we ascribe this to individual variation.

Two of the three post-embryonic nymphal stages (deutonymph and tritonymph) are present in the samples, and they 
exhibit the same trichobothrial pattern as illustrated for $L$. aalbui (under the name Archeolarca aalbui) by Harvey (1992).

Family Chernetidae Menge 1855

Subfamily Chernetinae Menge 1855

Hesperochernes Chamberlin 1924

Hesperochernes Chamberlin 1924:89-90.

Type species.-Hesperochernes laurae Chamberlin 1924, by original designation.

Remarks.-The genus Hesperochernes currently comprises 19 North American species, ranging as far south as the Dominican Republic and Mexico (e.g., Ellingsen 1910; Chamberlin 1924; Beier 1933, 1976) and as far north as Canada (Hoff 1945), and a single Japanese species (Sato 1983). Muchmore (1974) provided details on how to separate Hesperochernes from the morphologically similar genera Chernes Menge 1855 and Dinocheirus Chamberlin 1929, but admitted that the composition of the genus was not fully resolved due to uncertainties in the morphology of several species. Hesperochernes is currently diagnosed by the following combination of characters: rallum composed of 4 blades; tarsus III and IV without conspicuous tactile seta; setae of pedipalps and tergites not large and leaf-like; female spermathecae with long paired ducts terminating in rounded sacs; and cheliceral setae $b s$ and $s b s$ usually dentate or denticulate. Of these characters, Muchmore (1974) was only able to nominate the spermathecal morphology and the denticulate $b s$ and $s b s$ as features that distinguish it from Chernes. It appears, however, that some species currently assigned to Hesperochernes have an acuminate $b s$, including $H$. canadensis, $H$. holsingeri, $H$. molestus, H. montanus, $H$. occidentalis and $H$. riograndensis (Chamberlin 1935; Hoff 1945; Hoff \& Clawson 1952; Hoff 1956b; Hoff \& Bolsterli 1956; Muchmore 1994). Moreover, the new species described below clearly demonstrates the labile nature of this feature, with the male having a strongly denticulate $b s$ on both chelicerae, but the two females having an acuminate $b s$. It would seem that this feature should be used with considerable caution, and that the nature of the spermathecae is the only feature that can be reliably used to separate Hesperochernes from Chernes.

Although Muchmore (1974) was able to confirm the generic placement of several species from the U.S.A. and Canada [H. laurae, H. mimulus Chamberlin 1952, H. mirabilis (Banks 1895), H. molestus Hoff 1956, H. occidentalis (Hoff and Bolsterli 1956). H. riograndensis Hoff and Clawson 1952, $H$. tamiae Beier 1930, and H. utahensis Hoff and Clawson 1952], he was not able to ascertain whether others were correctly placed [H. canadensis Hoff 1945, H. montanus Chamberlin 1935, H. pallipes (Banks 1893), H. paludis (Moles 1914), H. thomomysi Hoff 1948, and H. unicolor (Banks 1908)]. The same can be said of the Central American and Asian species currently included in Hesperochernes, H. globosus (Ellingsen 1910), H. tumidus Beier 1933 and H. inusitatus Hoff 1946 from Mexico, H. vespertilionis Beier 1976 from Dominican Republic, and H. shinjoensis Sato 1983 from Japan, as the morphology of the spermathecae has not yet been ascertained (Ellingsen 1910; Beier 1933; Hoff 1946a; Beier 1976; Sato 1983).

Species of Hesperochernes are frequently collected in caves or are associated with other animals. The cave-dwelling species include three eyeless species that have long slender pedipalps consistent with strong troglomorphisms, $H$. holsingeri, $H$. mirabilis and $H$. occidentalis, as well as the new eyeless species described below that has long legs but has robust pedipalps. The species associated with rodents include $H$. mimulus, $H$. molestus, $H$. riograndensis, $H$. tamiae, $H$. thomomysi and $H$. utahensis (Beier 1930; Hoff 1945, 1946b; Chamberlin 1952; Hoff \& Clawson 1952; Hoff 1956b), while $H$. vespertilionis was collected within a bat roost (Beier 1976). Hesperochernes laurae and H. unicolor were found within both wasp's and ant's nests (Banks 1908; Chamberlin 1924; Hoff 1947), respectively, $H$. montanus was found in a bird's nest (Chamberlin 1935), and H. tumidus was collected "lying on the ground in pods of Inga sp." (translated from the original German) (Beier 1933). The poorly described and most likely misplaced $H$. paludis was taken from both rotten poplar tree logs on the ground and live standing poplar trees (Moles 1914), and the only species recorded from outside of North America, H. shinjoensis from northern Japan, was collected from under tree bark (Sato 1983). The other species lack any habitat data.

\section{Hesperochernes bradybaughi sp. nov.}

urn:lsid:zoobank.org:act:5419D319-EF22-4722-926F-1F8EC 080400B

Figs. 15-26

Material examined.-Types. U.S.A.: Arizona: Mohave County: holotype male, PARA-1001 Cave, Grand CanyonParashant National Monument, ca. UTM 0264500 N, 4060700 E, Zone 12S, baited pitfall trap 3B, 20 August 2007, J.J. Wynne (MNA); 1 female, same data as holotype except baited pitfall trap 5A (MNA); 1 female, same data as holotype except opportunistic, mid cave, 13 August 2005 (NMA).

Etymology.-This species is named for Jeff Bradybaugh, former superintendent of Grand Canyon-Parashant National Monument and an advocate for cave research, conservation and management both on Parashant and within the National Park Service.

Diagnosis.-Hesperochernes bradybaughi most closely resembles three other species of the genus that are also completely eyeless and have long slender legs [e.g. femur + patella IV 5.19 (male), 5.37-5.56 (female) $\times$ longer than broad], $H$. mirabilis, $H$. holsingeri and $H$. riograndensis. Hesperochernes bradybaughi lacks the slender pedipalps characteristic of $H$. mirabilis and $H$. holsingeri, and the male chela of $H$. bradybaughi is markedly swollen, especially on the dorsal face (Fig. 21), unlike the male of $H$. riograndensis which is not swollen. It is also substantially larger than $H$. riograndensis, e.g., chela (without pedicel) of $H$. riograndensis is 0.956 (male), 0.970 (female) $\mathrm{mm}$, whereas H. bradybaughi is 1.434 (male), 1.502-1.510 (female) mm.

Description.-Adults: Color: pedipalps and carapace dark red-brown, legs light red-brown, tergites yellow-brown, sternites pale yellow-brown.

Chelicera: with 5 setae on hand and 1 subdistal seta on movable finger (Fig. 23); setae $l s$ and is acuminate, es and $b s$ dentate, $s b s$ denticulate in female, acuminate in male; with 2 dorsal lyrifissures and 1 ventral lyrifissure; galea of $\hat{s}$ and $q$ with 6 rami; rallum of 4 blades, the 2 distal blades with several 

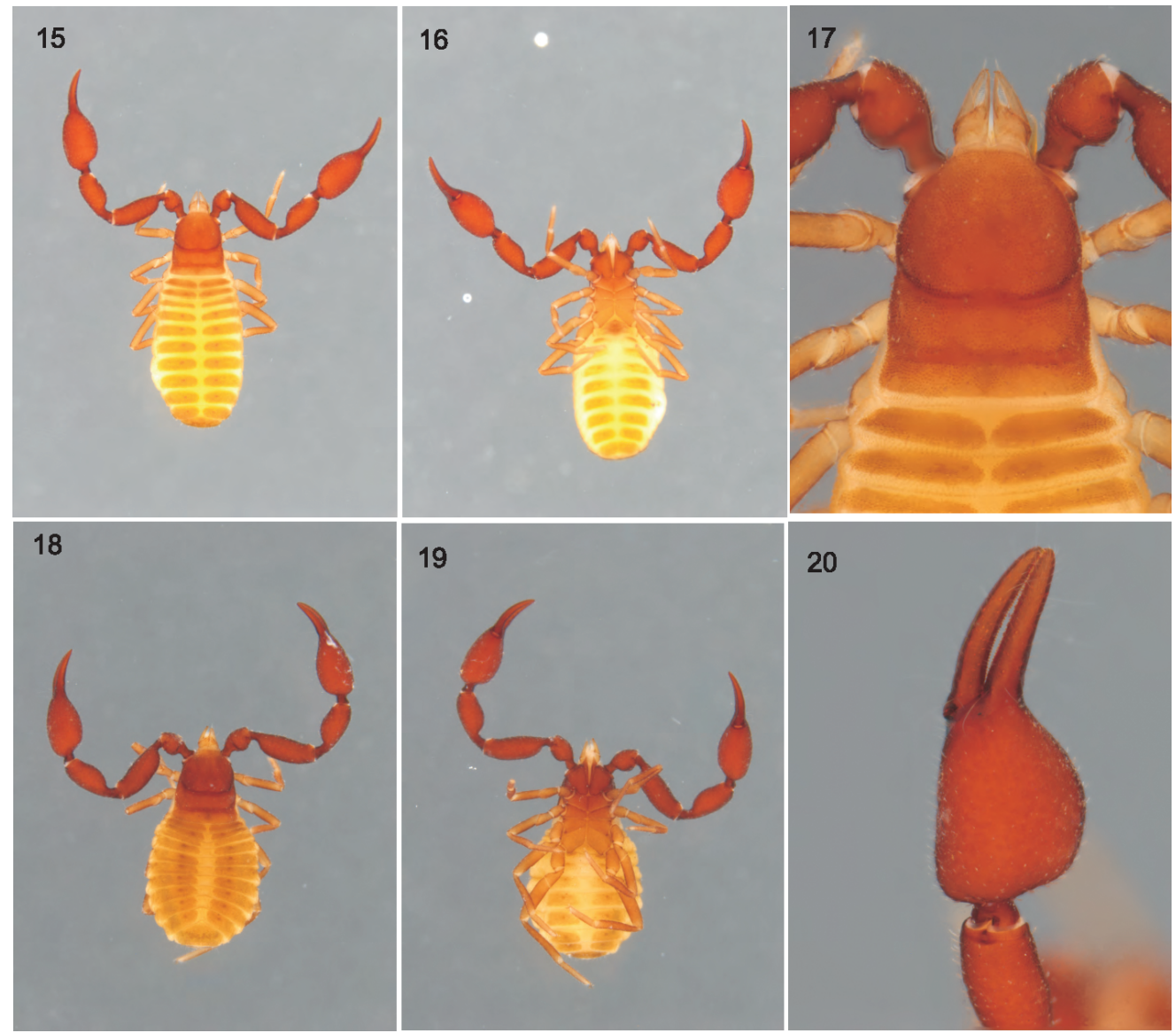

Figures 15-20.-Hesperochernes bradybaughi, sp. nov.: 15. Body, dorsal, male holotype; 16. Body, ventral, male holotype; 17. Carapace, dorsal, male holotype; 18. Body, dorsal, female paratype; 19. Body, ventral, female paratype; 20. Left chela, lateral, male holotype.

serrations on leading edge, other blades smooth; serrula exterior with $18\left({ }^{t}\right), 17$ ( + ) blades; lamina exterior present.

Pedipalp (Fig. 24): surfaces of trochanter, femur, patella and chelal hand coarsely granulate, chela fingers mostly smooth; patella with 5 small sub-basal lyrifissures; trochanter $1.84\left({ }^{3}\right), 1.86-1.88$ ( $)$, femur $3.17\left({ }^{3}\right), 2.95-3.09$ ( $)$, patella $2.62\left(0^{3}\right), 2.54-2.66(+)$, chela (with pedicel) $3.07\left({ }^{3}\right), 3.23-3.34$ ( $)$, chela (without pedicel) $2.83\left({ }^{3}\right), 2.98-3.09$ ( $($ ), hand 1.49 (o), 1.34-1.64 ( $) \times$ longer than broad, movable finger 0.93 (3), $0.86-0.96(+) \times$ longer than hand. Fixed chelal finger with 8 trichobothria, movable chelal finger with 4 trichobothria (Figs. 21, 22): $e b$ and $e s b$ situated basally, $i b$ and ist subbasally, est and isb submedially, et and it subdistally, isb situated midway between ist and $i t$, and et slightly distal to $i t ; t$ situated subdistally, st situated closer to $t$ than to $s b$. Venom apparatus only present in movable chelal finger, venom ducts long, terminating in nodus ramosus distal to $s t$ (Figs. 21, 22). Fixed finger with 2 large sensillae on retrolateral face, and 2 on prolateral face; movable chelal finger with sensilla slightly proximal to $s b$ in male and slightly distal to $s b$ in female, with 2 receptors. Chela of male without mound. Chelal teeth pointed and slightly retrorse, basal teeth more rounded; fixed finger with $44\left({ }^{\circ}\right), 48\left({ }^{\circ}\right)$ teeth, plus $11\left(\hat{o}^{*}\right), 9\left({ }^{\circ}\right)$ retrolateral and $10(\delta), 7$ ( + ) prolateral accessory teeth; movable finger with $46\left({ }^{\circ}\right), 50(\%)$ teeth, plus $9(\hat{\delta}, 9)$ retrolateral and $6\left({ }^{*}\right), 4(+)$ prolateral accessory teeth.
Carapace (Fig. 17): coarsely granulate, $1.15\left({ }^{*}\right), 0.98-1.10$ (\%) $\times$ longer than broad; without eyes or eyespots; with 100 (3), 83 (\%) setae, arranged with $61\left({ }^{3}\right), 42$ ( + ( ) (including 6 near anterior margin) in anterior zone, $25(\hat{)}), 34(+)$ in median zone, and $14\left({ }^{3}\right), 17$ ( $($ ) in posterior zone; with 2 deep furrows, posterior furrow situated slightly closer to posterior carapace margin than to anterior furrow.

Coxal region: maxillae granulate; manducatory process somewhat acute, with 2 apical acuminate setae, 1 small suboral seta and $37\left({ }^{\hat{\delta}}\right), 32(+)$ additional setae; median maxillary lyrifissure rounded and situated submedially; posterior maxillary lyrifissure rounded. Leg coxae smooth; chaetotaxy of coxae I-IV: ô, 18: 19: 23: ca. 60; ㅇ, 18: 21: 25: ca. 65.

Legs: very slender; junction between femora and patellae I and II strongly oblique to long axis; junction between femora and patellae III and IV very angulate; femora III and IV much smaller than patellae III and IV; femur + patella of leg IV 5.19 (3), 5.37-5.56 ( $) \times$ longer than broad; all tarsi with slit sensillum on raised mound; male leg I not modified; tarsi III and IV without tactile seta, but with paired subdistal setae; subterminal tarsal setae arcuate and acute; claws simple; arolium about same length as claws, not divided.

Abdomen: tergites $\mathrm{I}-\mathrm{X}$ and sternites IV-X of male and female with median suture line fully dividing each segment. Tergal chaetotaxy: ô, 11: 12: 11:18: 19: 18: 20: 18: 17: 18: 13:2; ㅇ, 12: 13: 13: 17: 17: 18: 19: 19: 21: 16: 14: 2; uniseriate, except 

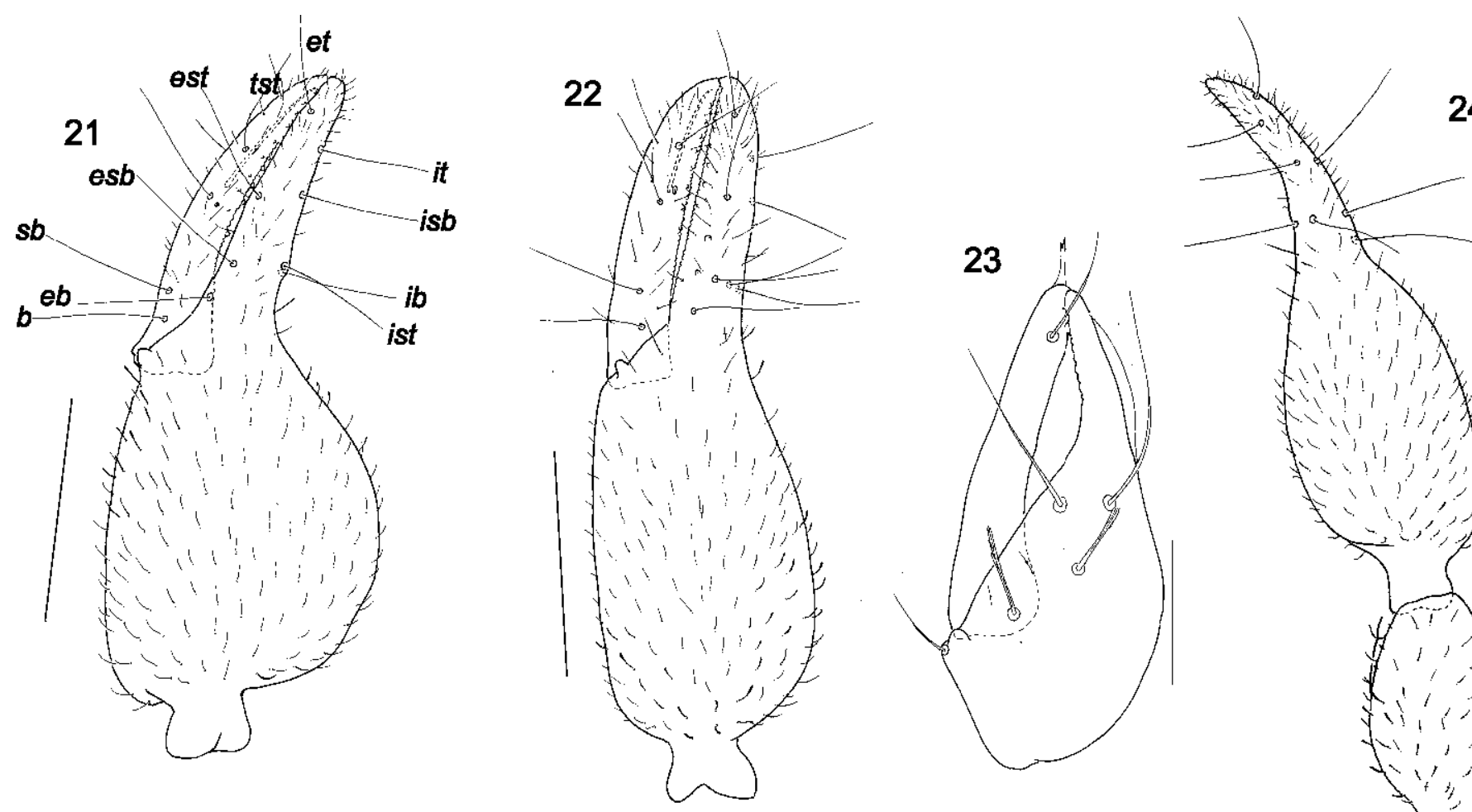

24
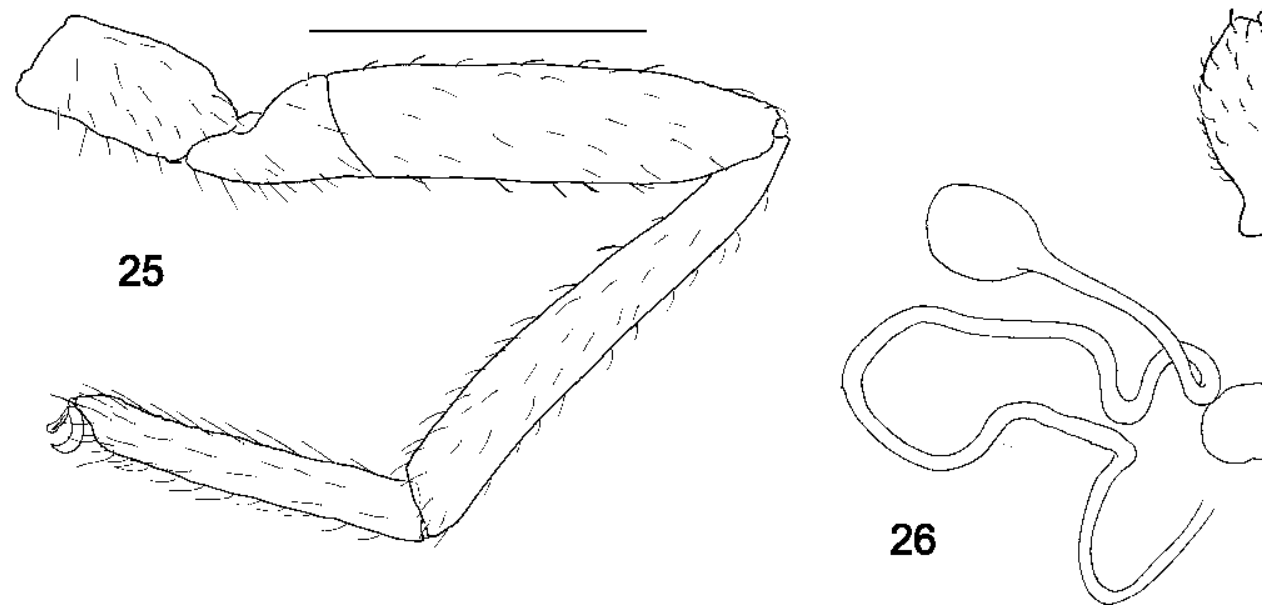

Figures 21-26.-Hesperochernes bradybaughi, sp. nov.: 21. Left chela, lateral, male holotype; 22. Left chela, lateral, female paratype; 23. Chelicera, dorsal, female paratype; 24. Right pedipalp, dorsal, male holotype; 25. Left leg IV, male holotype; 26. Spermathecae, female paratype. Scale lines $=0.1 \mathrm{~mm}$ (Fig. 23), $0.2 \mathrm{~mm}$ (Fig. 26), $0.5 \mathrm{~mm}$ (Figs. 21, 22, 24, 25).

for medial and lateral discal seta on tergites IV-IX; setae thickened and strongly dentate. Sternal chaetotaxy: ô, 30: (3) 22 $[2+2]$ (3): (1) 8 (1): 19: 21:21: 20: 20: 16: 8 (arranged T6T): 2; , ca. 40: (3) 10 (3): (1) 5 (1): 14: 21: 20: 20: 18: 16: 11 (arranged T9T): 2; uniseriate, except for lateral discal seta on sternites VII-X; setae of anterior sternites acicular, becoming progressively more denticulate on posterior sternites. Spiracles with helix. Anal plates (tergite XII and sternite XII) situated between tergite XI and sternite XI, anal setae not denticulate. Pleural membrane wrinkled and somewhat stellate; without any setae.

Genitalia: male of the chernetid type. Female (Fig. 26): with a pair of long thin-walled spermathecae terminating in rounded sacs.
Dimensions: Male holotype: Body length 3.11. Pedipalps: trochanter $0.518 / 0.282$, femur $974 / 0.307$, patella $0.824 / 0.314$, chela (with pedicel) $1.552 / 0.506$, chela (without pedicel) 1.434 , hand length 0.756, movable finger length 0.704. Chelicera $0.322 / 0.165$, movable finger length 0.252. Carapace 0.956/ 0.830. Leg I: femur $0.268 / 0.161$, patella $0.495 / 0.136$, tibia $0.503 / 0.102$, tarsus $0.495 / 0.079$. Leg IV: femur + patella 0.883 / 0.170 , tibia $0.778 / 0.107$, tarsus $0.557 / 0.085$.

Female (paratype lodged in MNA) followed by other female (where applicable): Body length 2.82 (4.21). Pedipalps: trochanter 0.552/0.294 (0.566/0.304), femur 1.034/0.335 (1.042/ $0.353)$, patella $0.904 / 0.340(0.942 / 0.371)$, chela (with pedicel) $1.624 / 0.486$ (1.635/0.506), chela (without pedicel) 1.502 
(1.510), hand length 0.797 (0.698), movable finger length 0.768 (0.816). Chelicera $0.327 / 0.152$, movable finger length 0.244 . Carapace 1.040/0.944 (1.000/1.021). Leg I: femur 0.300/0.182, patella $0.540 / 0.146$, tibia $0.56 / 0.108$, tarsus $0.520 / 0.079$. Leg IV: femur + patella $1.010 / 0.188(1.000 / 0.180)$, tibia $0.830 /$ 0.121 , tarsus $0.580 / 0.084$.

Remarks.-As stated in the diagnosis, H. bradybaughi appears to be most similar to $H$. riograndensis but differs in being substantially larger and with a markedly swollen male chela, especially on the dorsal face. The only known location of $H$. riograndensis is located $670 \mathrm{~km}$ ESE of Parashant, and the microhabitat of both species differs with $H$. bradybaughi being found in a cave and $H$. riograndensis collected from the nest of a kangaroo rat (Heteromyidae: Dipodomys) (Hoff \& Clawson 1952). Given the lack of eyes and eyespots, we consider $H$. bradybaughi to be a troglobite.

\section{Tuberochernes Muchmore}

Tuberochernes Muchmore 1997:206-207.

Type species.-Tuberochernes aalbui Muchmore 1997, by original designation.

Diagnosis.-Tuberochernes differs from all other chernetid genera by the combined presence of a distinct medium-sized mound on the prolateral face of the pedipalpal chela of males, and four blades in the cheliceral rallum.

Remarks.-The genus Tuberochernes was described by Muchmore (1997) for two species of cave-dwelling pseudoscorpions from southwestern U.S.A., T. aalbui and T. ubicki, but the discovery of a third species, also from a cave in southwestern U.S.A., does not necessitate an alteration of the original description apart from the nature of the tactile seta of leg IV. Muchmore (1997) observed that the tactile seta of leg IV was "short, distally located" and "variably acuminate or finely denticulate". Close examination of the posterior tarsi of the new species described below does not reveal a tactile seta of this nature, and we suggest this feature appears to be variable within the genus.

The most obvious feature that distinguishes Tuberochernes is the presence of a medium-sized mound on the prolateral margin of the chelal hand in males (Muchmore 1997). In this respect, it resembles several other chernetid genera, including males of Mirochernes Beier 1930 and Bituberochernes Muchmore 1974, and both males and females of Interchernes Muchmore 1980 and Petterchernes Heurtault 1986, which were distinguished from Tuberochernes by Muchmore (1997). Bituberochernes further differs from Tuberochernes by a mound being also present on the pedipalpal patella. The function of the mound has not been ascertained, but the mound of $T$. cohni has 5 small pores, which may be responsible for discharging fluids, possibly during sexual interactions with females.

Tuberochernes cohni sp. nov.

urn:1sid:zoobank.org:act:12896B35-DD1C-4E0B-B66F-F9B $30170 \mathrm{D} 476$

Figs. 27-37

Material examined.-Type: U.S.A.: Arizona: Mohave County: holotype male, PARA-1001 Cave, Grand CanyonParashant National Monument, ca. UTM $0264500 \mathrm{~N}$,
$4060700 \mathrm{E}$, Zone 12S, the deeper extent of the twilight zone (near the dark zone), opportunistic collecting, 13 August 2005, J.J. Wynne (MNA).

Etymology.-This species is named for the late Dr. Theodore "Ted" Cohn. Cohn was an Orthopterist and the leading authority who identified the new genus of rhaphidophorid cricket known from PARA-1001 Cave. Dr. Cohn passed away in November 2013 at age 82. He was a passionate educator and entomologist.

Diagnosis.-Tuberochernes cohni differs from the other two species of the genus, T. aalbui and T. ubicki, by the more anteriorly positioned mound on the pedipalpal chela.

Description.-Adult male: Color: pedipalps and carapace dark red-brown, legs light red-brown, tergites yellow-brown, sternites pale yellow-brown.

Chelicera: with 6 setae on hand and 1 subdistal seta on movable finger (Fig. 32); setae es, $s b s$ and $b s$ dentate, $l s$ and is acuminate; with 2 dorsal lyrifissures and 1 ventral lyrifissure; galea broken; rallum of 4 blades, the most distal blade with several serrations on leading edge, other blades smooth; serrula exterior with 17 blades; lamina exterior present.

Pedipalp (Fig. 33): surfaces of trochanter, femur, patella and chelal hand coarsely granulate, chela fingers mostly smooth; patella with 5 small sub-basal lyrifissures; trochanter 1.73 , femur 2.83, patella 2.88 , chela (with pedicel) 3.39 , chela (without pedicel) 3.11 , hand $1.40 \times$ longer than broad, movable finger $1.23 \times$ longer than hand. Fixed chelal finger with 8 trichobothria, movable chelal finger with 4 trichobothria (Fig. 31): $e b$ and $e s b$ situated basally, $i b$ and ist subbasally, est and isb submedially, et and it subdistally, isb situated midway between ist and it, and et slightly distal to it; $t$ situated subdistally, st situated much closer to $t$ than to $s b$. Venom apparatus only present in movable chelal finger, venom ducts long, terminating in nodus ramosus midway at level of st (Fig. 31). Fixed finger with 3 sensillae on retrolateral face, and 1 on prolateral face; movable chelal finger with sensilla slightly distal to sb, with 2 receptors. Chela with prominent, medium-sized mound on prolateral face (Figs. 30, 34), with 5 small pores. Chelal teeth pointed and slightly retrorse, basal teeth more rounded; fixed finger with 37 teeth, plus 7 retrolateral and 3 prolateral accessory teeth; movable finger with 42 teeth, plus 4 retrolateral and 0 prolateral accessory teeth.

Carapace (Fig. 29): coarsely granulate, $1.19 \times$ longer than broad; without eyes or eyespots; with 96 setae, arranged with 54 (including 6 near anterior margin) in anterior zone, 28 in median zone, and 14 in posterior zone; with 2 deep furrows, posterior furrow situated closer to posterior carapace margin than to anterior furrow.

Coxal region: maxillae granulate; manducatory process somewhat acute, with 2 apical acuminate setae, 1 small suboral seta and 25 additional setae; median maxillary lyrifissure rounded and situated submedially; posterior maxillary lyrifissure rounded. Leg coxae smooth; chaetotaxy of coxae I-IV: 13: 12: $14: 34$.

Legs (Figs. 35-37): junction between femora and patellae I and II strongly oblique to long axis; junction between femora and patellae III and IV very angulate; femora III and IV much smaller than patellae III and IV; femur + patella of leg IV 4.03 $\times$ longer than broad; all tarsi with slit sensillum on raised 

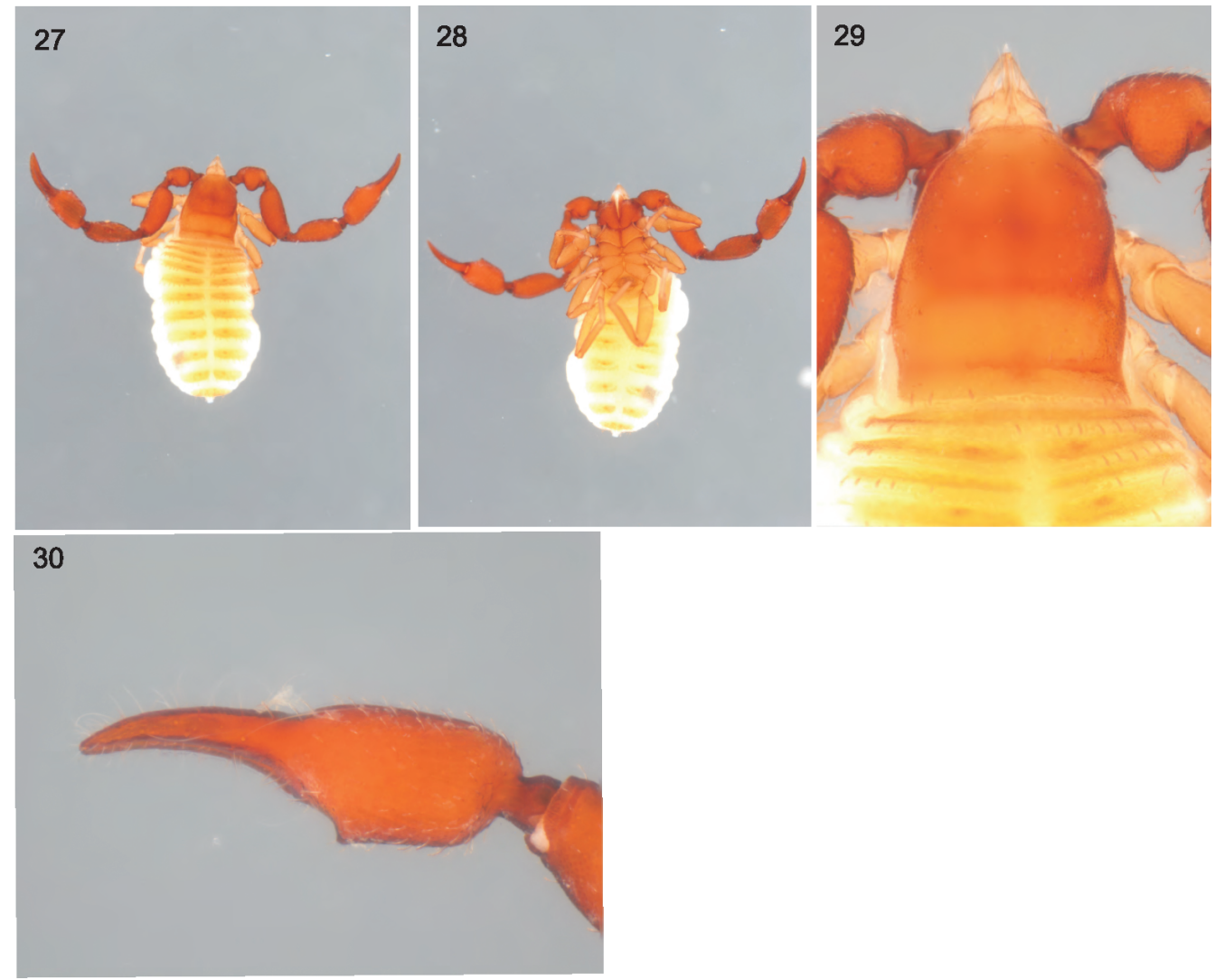

Figures 27-30.-Tuberochernes cohni, sp. nov., male holotype: 27. Body, dorsal; 28. Body, ventral; 29. Carapace, dorsal; 30. Right chela, dorsal.

mound; leg I modified with tibia thickened, tarsus slightly curved and ventral margins of patella and tibia with coarse granulation; tarsi III and IV without tactile seta, but with paired subdistal setae; subterminal tarsal setae arcuate and acute; claws simple; arolium about same length as claws, not divided.

Abdomen: tergites II-X and sternites $\mathrm{V}-\mathrm{X}$ of with median suture line fully dividing each segment. Tergal chaetotaxy: 15: 20: 20: 20: 22: 22: 21: 21: 22: 17: 10: 2; uniseriate, except for medial and lateral discal seta on tergites IV-IX; setae thickened and strongly dentate. Sternal chaetotaxy: 51: (0) 8 [2+2] (0): (1) 8 (1): 12: 16: 17: 18: 17: 14: 8 (arranged T6T): 2; uniseriate, except for lateral discal seta on sternites IV-XI; setae of anterior sternites acicular, becoming progressively more denticulate on posterior sternites. Spiracles with helix. Anal plates (tergite XII and sternite XII) situated between tergite XI and sternite XI, anal setae denticulate. Pleural membrane longitudinally striate; without any setae.

Genitalia: of the chernetid type.

Dimensions: male holotype: Body length 3.38. Pedipalps: trochanter $0.576 / 0.332$, femur $0.944 / 0.334$, patella $0.910 / 0.316$, chela (with pedicel) $1.390 / 0.410$, chela (without pedicel) 1.276 , hand length 0.573 , movable finger length 0.704 . Chelicera $0.333 / 0.134$, movable finger length 0.240 . Carapace $1.009 /$ 0.848. Leg I: femur $0.305 / 0.249$, patella $0.560 / 0.253$, tibia $0.621 / 0.174$, tarsus $0.442 / 0.089$. Leg IV: femur + patella $0.859 /$ 0.213 , tibia $0.692 / 0.134$, tarsus $0.533 / 0.954$.

Remarks.-Tuberochernes cohni possesses some very slight modifications consistent with troglomorphic adaptations of which the most prominent is the complete lack of eyes (Fig. 29) and the slightly elongated leg segments. Thus, this animal is considered a troglobite. It appears to bear a closer resemblance to $T$. ubicki from a cave in the Santa Rita Mountains, Arizona (610 km), than to T. aalbui from a cave in the Inyo National Forest, California $(415 \mathrm{~km})$, due to the similarly expanded tibia I in males of the two Arizona species.

\section{DISCUSSION}

Our review of the pseudoscorpions detected within the caves of Grand Canyon-Parashant National Monument has revealed a modest fauna of three species: Larca cavicola (family Larcidae), Hesperochernes bradybaughi and Tuberochernes cohni (both in the family Chernetidae). All show modifications consistent with obligate existence in cave environments, but none show the classic signs of extreme troglomorphism found in many cave-adapted pseudoscorpions (e.g. Heurtault 1994; Harvey et al. 2000). Both species of Chernetidae lack eyes and have long slender legs, which appear to be troglomorphic modifications due to their subterranean existence, although their pedipalps do not appear to be modified compared to epigean species of the genus. Other subterranean species of Hesperochernes with thin legs and no eyespots- $H$. holsingeri from Indiana, H. mirabilis from Alabama, Georgia, Indiana, Kentucky, Ohio, Tennessee and Virginia, and H. occidentalis from Arkansas, Missouri, Oklahoma and Texas - appear to be more highly modified as they have elongate pedipalps. Both new species described from the Parashant may represent shortrange endemic species as defined by Harvey (2002) and Harvey 

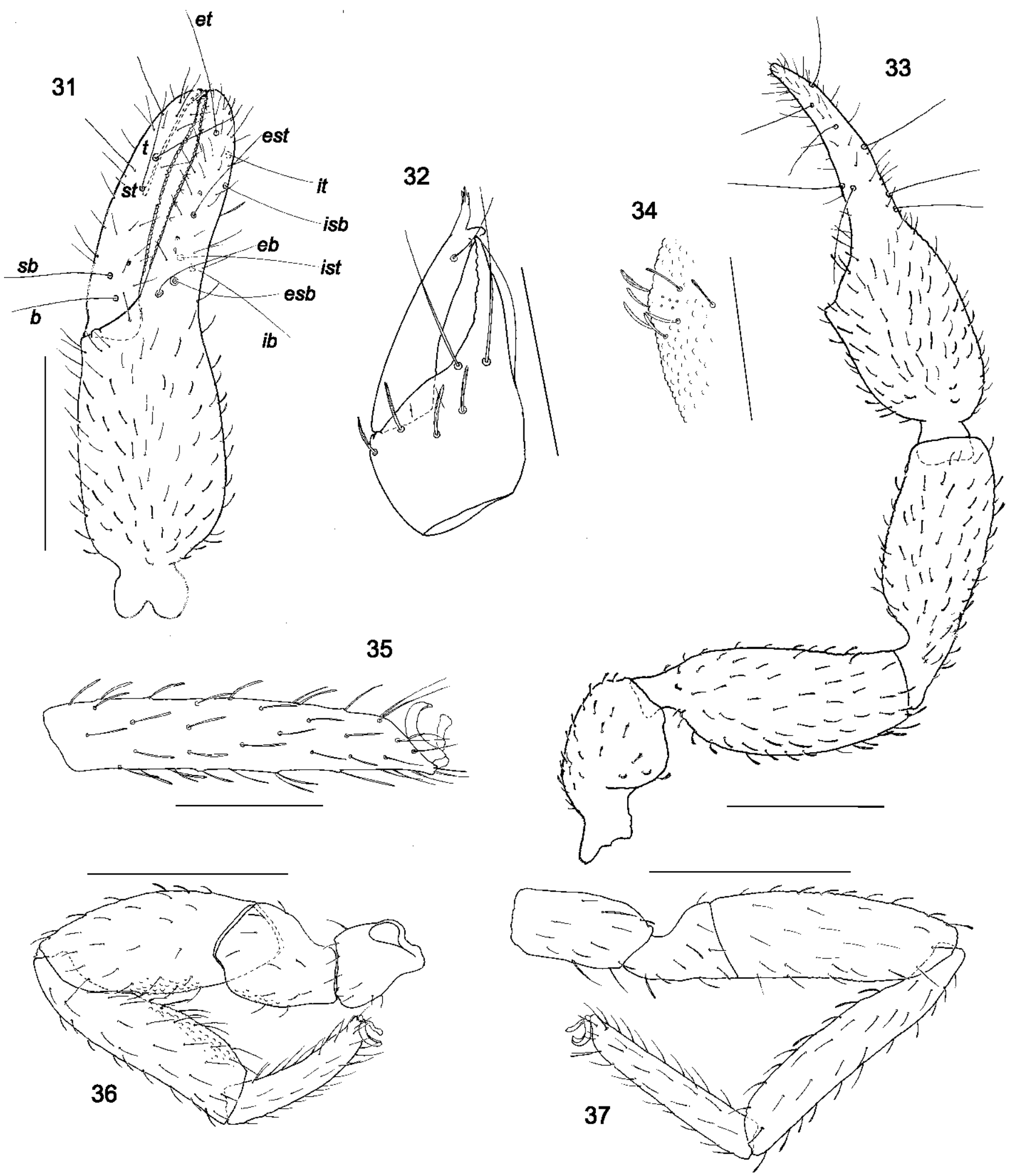

Figures 31-37.-T Tuberochernes cohni, sp. nov., male holotype: 31. Left chela, lateral; 32. Chelicera, dorsal; 33. Right pedipalp, dorsal; 34. Left chela, detail of mound, ventral; 35. Left tarsus IV; 36. Left I; 37. Left leg IV. Scale lines $=0.2 \mathrm{~mm}$ (Figs. 32, 34, 35), 0.5 mm (Figs. 31, 33, 36, 37). 
et al. (2011) due to their highly restricted distributions. Although the junior author and colleagues sampled all known caves on Parashant, they detected these new species in only one cave (PARA-1001 Cave).

Larca cavicola appears to be less cave-adapted than the others, as it retains eyes. However, the pedipalps are noticeably thinner than epigean species of the genus, suggesting moderate morphological modifications to the cave environment. Larca cavicola was found in PARA-3503 and PARA-2204 Caves and has been found in Cave of the Domes, a small cave situated within Grand Canyon National Park, Coconino County (Muchmore 1981). Although this cave is also located in the Grand Canyon region, it lies on the south side of the Colorado River some $160 \mathrm{~km}$ from the Parashant caves, and we suggest these populations are genetically isolated from each other.

The only known locality of Hesperochernes bradybaughi and Tuberochernes cohni is PARA-1001. This is the second most biologically diverse cave, and the most biologically significant cave on the monument. It supports the largest known cricket roost in Arizona, which represents an undescribed genus of rhaphidophorid cave cricket, cf Ceuthophilus n. gen. n. sp., Cohn \& Swanson, unpublished data; (Wynne \& Voyles 2014). Its population contributes significantly to the nutrient loading via cricket guano, cricket eggs and nymphs, as well as deceased individuals at various life stages. In other regions, the ecological importance of crickets on cave ecosystems is well documented (e.g., Barr 1967; Howarth 1983; Taylor 2003; Culver 2005; Poulson 2005). Given the size of the roost, we suggest that cf Ceuthophilus n. gen. n. sp. represents a keystone species with the presence of this animal supporting at least four cave-adapted species including a short-range endemic and troglomorphic leiodid beetle, Ptomaphagus parashant (Peck \& Wynne 2013), an undescribed species of troglomorphic centipede (family Anopsobiidae; Wynne, unpublished data), and the two pseudoscorpion species described here. To date, $P$. parashant, the anopsobiid centipede, and the two new pseudoscorpion species have been detected only in PARA1001 Cave. Two other caves on the monument, with similar deep zone like conditions, were sampled using the same systematic sampling design are within a $9.7 \mathrm{~km}$ radius of PARA-1001; neither of these new pseudoscorpions species were detected at these caves.

Management Implications. - We recommend the same management strategies proposed by Peck \& Wynne (2013) be maintained for PARA-1001 Cave. This cave should not be gated given its south-facing entrance and entrance structure, and it should remain closed to recreational use. PARA-1001 is considered the second most biologically diverse cave on the monument and supports the greatest diversity of troglomorphic arthropod species. Presently, all of these animals (including the two new pseudoscorpion species described here) are known to occur only within PARA-1001 Cave. Maintaining the management strategies suggested by Peck \& Wynne (2013) should aid in the long-term persistence of these presumed short-range endemic arthropods.

\section{ACKNOWLEDGMENTS}

Special thanks to Jennifer Fox, Eathan McIntyre, Ray Klein and Rosie Pepito of Grand Canyon-Parashant National
Monument, Danielle Nelson and Matt Johnson with the Colorado Plateau Research Station, and Neil Cobb of the Colorado Plateau Museum of Arthropod Biodiversity for administrative and logistical support. Tama and John Cassidy, Michael Gowan, John Kalman, Ty Spatta and Kyle Voyles assisted with fieldwork. The San Bernardino Cave Search and Rescue Team, Jon Jasper and Kyle Voyles, remained on emergency stand-by during field operations. Dave Decker and Kyle Voyles provided descriptions regarding the geological and structural characteristics of the study caves. Dale Pate and two anonymous reviewers provided suggestions leading to the improvement of this manuscript. The Explorers Club recognized two of these research trips as flag expeditions. Fieldwork was funded through a Colorado Plateau CESU cooperative agreement between the National Park Service and Northern Arizona University.

\section{LITERATURE CITED}

Aalbu, R.L., A.D. Smith \& C.A. Triplehorn. 2012. A revision of the Eleodes (subgenus Caverneleodes) with new species and notes on cave breeding Eleodes (Tenebrionidae: Amphidorini). Annales Zoologica 62:199-216.

Ashmole, N.P., P. Oromí, M.J. Ashmole \& J.L. Martín. 1992. Primary faunal succession in volcanic terrain: lava and cave studies on the Canary Islands. Biological Journal of the Linnean Society 46:207-234.

Banks, N. 1908. The pseudoscorpions of Texas. Bulletin of the Wisconsin Natural History Society 6:39-42.

Barber, H.S. 1931. Traps for cave inhabiting insects. Journal of the Mitchell Society 46:259-266.

Barr, T.C. Jr. 1967. Observations on the ecology of caves. American Naturalist 101:475-491.

Beier, M. 1930. Die Pseudoskorpione des Wiener Naturhistorischen Museums. III. Annalen des Naturhistorischen Museums in Wien 44:199-222.

Beier, M. 1933. Pseudoskorpione aus Mexiko. Zoologischer Anzeiger 104:91-101.

Beier, M. 1939a. Die Pseudoscorpioniden-Fauna der iberischen Halbinsel. Zoologische Jahrbücher, Abteilung für Systematik, Ökologie und Geographie der Tiere 72:157-202.

Beier, M. 1939b. The Pseudoscorpionidea collected by the Percy Sladen Trust Expedition to Lake Titicaca. Annals and Magazine of Natural History (11) 3:288-290.

Beier, M. 1947. Zur Kenntnis der Pseudoscorpionidenfauna des südlichen Afrika, insbesondere der südwest- und südafrikanischen Trockengebiete. Eos, Madrid 23:285-339.

Beier, M. 1962. Pseudoscorpioniden aus der Namib-Wüste. Annals of the Transvaal Museum 24:223-230.

Beier, M. 1973. Weiteres zur Kenntnis der Pseudoscorpioniden Südwestafrikas. Cimbebasia, A 2:97-101.

Beier, M. 1976. Pseudoscorpione von der Dominicanischen Republik (Insel Haiti). Revue Suisse de Zoologie 83:45-58.

Benedict, E.M. \& D.R. Malcolm. 1978. Some garypoid false scorpions from western North America (Pseudoscorpionida: Garypidae and Olpiidae). Journal of Arachnology 5:113-132.

Chamberlin, J.C. 1924. Hesperochernes laurae, a new species of false scorpion from California inhabiting the nest of Vespa. Pan-Pacific Entomologist 1:89-92.

Chamberlin, J.C. 1930. A synoptic classification of the false scorpions or chela-spinners, with a report on a cosmopolitan collection of the same. Part II. The Diplosphyronida (Arachnida-Chelonethida). Annals and Magazine of Natural History (10) 5:1-48, 585-620.

Chamberlin, J.C. 1931. The arachnid order Chelonethida. Stanford University Publications, Biological Sciences 7(1):1-284. 
Chamberlin, J.C. 1935. A new species of false scorpion (Hesperochernes) from a bird's nest in Montana (Arachnida-Chelonethida). Pan-Pacific Entomologist 11:37-39.

Chamberlin, J.C. 1943. The taxonomy of the false scorpion genus Synsphyronus with remarks of the sporadic loss of stability in generally constant morphological characters (Arachnida: Chelonethida). Annals of the Entomological Society of America 36:486-500.

Chamberlin, J.C. 1952. New and little-known false scorpions (Arachnida, Chelonethida) from Monterey County, California. Bulletin of the American Museum of Natural History 99:259-312.

Culver, D.C. 2005. Species interactions. Pp. 539-543. In Encyclopedia of Caves. (D.C. Culver \& W.B. White, eds.). Elsevier, Burlington, Massachusetts.

Ellingsen, E. 1910. Die Pseudoskorpione des Berliner Museums. Mitteilung aus dem Zoologischen Museum in Berlin 4:357-423.

Gardini, G. 1983. Larca italica n. sp. cavernicola dell'Appennino Abruzzese (Pseudoscorpionida, Garypidae) (Pseudoscorpioni d'Italia XV). Bollettino della Società Entomologica Italiana 115:63-69.

Harvey, M.S. 1986. The Australian Geogarypidae, new status, with a review of the generic classification (Arachnida: Pseudoscorpionida). Australian Journal of Zoology 34:753-778.

Harvey, M.S. 1987a. Redescriptions of Geogarypus bucculentus Beier and G. pustulatus Beier (Geogarypidae: Pseudoscorpionida). Bulletin of the British Arachnological Society 7:137-141.

Harvey, M.S. 1987b. A revision of the genus Synsphyronus Chamberlin (Garypidae: Pseudoscorpionida: Arachnida). Australian Journal of Zoology, Supplementary Series 126:1-99.

Harvey, M.S. 1992. The phylogeny and classification of the Pseudoscorpionida (Chelicerata: Arachnida). Invertebrate Taxonomy 6:1373-1435.

Harvey, M.S. 2002. Short-range endemism in the Australian fauna: some examples from non-marine environments. Invertebrate Systematics 16:555-570.

Harvey, M.S. 2011. Two new species of Synsphyronus (Pseudoscorpiones: Garypidae) from southern Western Australian granite landforms. Records of the Western Australian Museum 26:11-22.

Harvey, M.S. \& K.L. Edward. 2007. A review of the pseudoscorpion genus Ideoblothrus (Pseudoscorpiones, Syarinidae) from western and northern Australia. Journal of Natural History 41:445-472.

Harvey, M.S. \& W.B. Muchmore. 2013. The systematics of the pseudoscorpion family Ideoroncidae (Pseudoscorpiones, Neobisioidea) in the New World. Journal of Arachnology 41:229-290.

Harvey, M.S., P.B. Ratnaweera, P.V. Randeniya \& M.R. Wijesinghe. 2012. A new species of the pseudoscorpion genus Megachernes (Pseudoscorpiones: Chernetidae) associated with a threatened Sri Lankan rainforest rodent, with a review of host associations of Megachernes. Journal of Natural History 46:2519-2535.

Harvey, M.S., M.G. Rix, V.W. Framenau, Z.R. Hamilton, M.S. Johnson, R.J. Teale, G. Humphreys \& W.F. Humphreys. 2011. Protecting the innocent: studying short-range endemic taxa enhances conservation outcomes. Invertebrate Systematics 25: $1-10$.

Harvey, M.S., W.A. Shear \& H. Hoch. 2000. Onychophora, Arachnida, myriapods and Insecta. Pp. 79-94. In Subterranean ecosystems. (H. Wilkens, D.C. Culver \& W.F. Humphreys, eds.). Elsevier, Amsterdam.

Henderickx, H. \& V. Vets. 2002. A new Larca (Arachnida: Pseudoscorpiones: Larcidae) from Crete. Bulletin of the British Arachnological Society 12:280-282.

Heurtault, J. 1994. Pseudoscorpions. Pp. 185-196. In Encyclopaedia biospeologica. (C. Juberthie \& V. Decu, eds.). Vol. 1. Société de Biospeologie, Moulis and Bucarest.

Hoff, C.C. 1945. Hesperochernes canadensis, a new chernetid pseudoscorpion from Canada. American Museum Novitates 1273:1-4.

Hoff, C.C. 1946a. New pseudoscorpions, chiefly neotropical, of the suborder Monosphyronida. American Museum Novitates 1318:1-32.
Hoff, C.C. 1946b. A study of the type collections of some pseudoscorpions originally described by Nathan Banks. Journal of the Washington Academy of Sciences 36:195-205.

Hoff, C.C. 1947. The species of the pseudoscorpion genus Chelanops described by Banks. Bulletin of the Museum of Comparative Zoology 98:471-550.

Hoff, C.C. 1950. Pseudoescorpionidos nuevos o poco conocidos de la Argentina (Arachnida, Pseudoscorpionida). Arthropoda, Buenos Aires 1:225-237.

Hoff, C.C. 1956a. Diplosphyronid pseudoscorpions from New Mexico. American Museum Novitates 1780:1-49.

Hoff, C.C. 1956b. Pseudoscorpions of the family Chernetidae from New Mexico. American Museum Novitates 1800:1-66.

Hoff, C.C. 1961. Pseudoscorpions from Colorado. Bulletin of the American Museum of Natural History 122:409-464.

Hoff, C.C. \& J.E. Bolsterli. 1956. Pseudoscorpions of the Mississippi River drainage basin area. Transactions of the American Microscopical Society 75:155-179.

Hoff, C.C. \& D.L. Clawson. 1952. Pseudoscorpions from rodent nests. American Museum Novitates 1585:1-38.

Howarth, F.G. 1980. The zoogeography of specialized cave animals: a bioclimatic model. Evolution 34:394 406.

Howarth, F.G. 1982. Bioclimatic and geological factors governing the evolution and distribution of Hawaiian cave insects. Entomologia Generalis 8:17-26.

Howarth, F.G. 1983. Ecology of cave arthropods. Annual Review of Entomology 28:365-389.

Judson, M.L.I. 2007. A new and endangered species of the pseudoscorpion genus Lagynochthonius from a cave in Vietnam, with notes on chelal morphology and the composition of the Tyrannochthoniini (Arachnida, Chelonethi, Chthoniidae). Zootaxa 1627:53-68.

Mahnert, V. 1982. Die Pseudoskorpione (Arachnida) Kenyas, IV. Garypidae. Annales Historico-Naturales Musei Nationalis Hungarici 74:307-329.

Mahnert, V. 1988. Zwei neue Garypininae-Arten (Pseudoscorpiones: Olpiidae) aus Afrika mit Bemerkungen zu den Gattungen Serianus Chamberlin und Paraserianus Beier. Stuttgarter Beiträge zur Naturkunde (A) 420:1-11.

Mockford, E.L. 2009. Systematics of North American species of Sphaeropsocidae (Psocoptera). Proceedings of the Entomological Society of Washington 11:666-685.

Moles, M. 1914. A pseudoscorpion from Poplar trees. Journal of Entomology and Zoology, Pomona College 6:81-83.

Muchmore, W.B. 1974. Clarification of the genera Hesperochernes and Dinocheirus (Pseudoscorpionida, Chernetidae). Journal of Arachnology 2:25-36.

Muchmore, W.B. 1981. Cavernicolous species of Larca, Archeolarca and Pseudogarypus with notes on the genera, (Pseudoscorpionida, Garypidae and Pseudogarypidae). Journal of Arachnology 9:4760.

Muchmore, W.B. 1982. The genus Anagarypus (Pseudoscorpionida: Garypidae). Pacific Insects 24:159-163.

Muchmore, W.B. 1984. New cavernicolous pseudoscorpions from California (Pseudoscorpionida, Chthoniidae and Garypidae). Journal of Arachnology 12:171-175.

Muchmore, W.B. 1990. Pseudoscorpionida. Pp. 503-527. In Soil biology guide. (D.L. Dindal, ed.). John Wiley and Sons, New York.

Muchmore, W.B. 1994. Some pseudoscorpions (Arachnida: Pseudoscorpionida) from caves in Ohio and Indiana, U.S.A. Transactions of the American Microscopical Society 113:316-324.

Muchmore, W.B. 1996. A remarkable new genus and species of Pseudoscorpionida (Syarinidae) from a cave in Arizona. Southwestern Naturalist 41:145-148.

Muchmore, W.B. 1997. Tuberochernes (Pseudoscorpionida, Chernetidae), a new genus with species in caves in California and Arizona. Journal of Arachnology 25:206-212. 
Muchmore, W.B. \& R.B. Pape. 1999. Description of an eyeless, cavernicolous Albiorix (Pseudoscorpionida: Ideoroncidae) in Arizona, with observations on its biology and ecology. Southwestern Naturalist 44:138-147.

Peck, S.B. \& J.J. Wynne. 2013. Ptomaphagus parashant Peck and Wynne, new species (Coleoptera: Leiodidae: Cholevinae: Ptomaphagini): the most troglomorphic cholevine beetle known from western North America. The Coleopterists Bulletin 67:309-317.

Poulson, T.L. 2005. Food sources. Pp. 255-264. In Encyclopedia of Caves. (D.C. Culver \& W.B. White, eds.). Elsevier, Burlington, MA.

Sato, H. 1983. Hesperochernes shinjoensis, a new pseudoscorpion (Chernetidae) from Japan. Bulletin of the Biogeographical Society of Japan 38:31-34.

Shear, W.A., S.J. Taylor, J.J. Wynne \& J.K. Krejca. 2009. Cave millipeds of the United States. VIII. New genera and species of polydesmidan millipeds from caves in the southwestern United States (Diplopoda, Polydesmida, Polydesmidae and Macrosternodesmidae). Zootaxa 2151:47-65.

Taylor, S.J. 2003. America, North: Biospeleology. Pp. 45-49. In Encyclopedia of Caves and Karst Science. (J. Gunn, ed.). Fitzroy Dearborn, New York, NY.

Wynne, J.J. \& K.D. Voyles. 2014. Cave-dwelling arthropods and vertebrates of North Rim Grand Canyon, with notes on ecology and management. Western North American Naturalist 74:1-17.

Zaragoza, J.A. 2005. Two new cave-dwelling Larca species from the south-east of Spain (Arachnida, Pseudoscorpiones, Larcidae). Revue Suisse de Zoologie 112:195-213.

Manuscript received 25 May 2014, revised 10 July 2014. 